\title{
Temperature influence on pathogen transmission and subsequent mortalities in juvenile Pacific oysters Crassostrea gigas
}

\author{
Bruno Petton ${ }^{1}$, Fabrice Pernet ${ }^{1,2, *}$, René Robert ${ }^{1}$, Pierre Boudry ${ }^{1}$ \\ ${ }^{1}$ Ifremer, UMR LEMAR 6539-Technopole de Brest-Iroise, BP 7029280 Plouzané, France \\ ${ }^{2}$ Ifremer, Laboratoire Environnement Ressources du Languedoc Roussillon, 34203 Sète, France
}

\begin{abstract}
Since 2008, mass mortalities of 1-yr-old Crassostrea gigas associated with the ostreid herpesvirus OsHV-1 $\mu$ Var have occurred along all the coasts of France when seawater temperature reaches 16 to $17^{\circ} \mathrm{C}$. The present study aimed to characterize the effect of temperature on oyster survival in combination with OsHV-1 DNA quantification by standard real-time PCR and total vibrio population levels in oyster tissues. To examine the effect of seawater temperature on disease transmission and related mortality of oysters, cohabitation experiments were conducted between healthy naïve oysters and oysters previously exposed to field conditions in areas where mortalities were occurring. Oysters initially maintained in controlled conditions (free of mortality and negative for OsHV-1), and then transferred to an area where high mortalities were occurring among farmed stocks, became infected with OsHV-1 and exhibited high loads of vibrios followed by significant mortalities. When previously exposed oysters were maintained indoors at $13.0^{\circ} \mathrm{C}$ for $40 \mathrm{~d}$ and then at $20.6^{\circ} \mathrm{C}$, they exhibited no mortality, were negative for OsHV-1 detection, and did not transmit the disease to healthy oysters. Survival of previously exposed oysters maintained indoors at 8 temperatures ranging from 13.4 to $29.0^{\circ} \mathrm{C}$ varied from 25 to $48 \%$ and was negatively correlated with holding temperature. Concomitantly, survival of naïve cohabiting animals (62 to $98 \%$ ) decreased with increasing seawater temperature until a plateau was reached between 16.2 and $21.9^{\circ} \mathrm{C}$, and increased at higher temperatures. Therefore, the optimal temperature range for disease transmission from field-exposed to naïve animals was between 16.2 and $21.9^{\circ} \mathrm{C}$. Our results suggest that a long-term period $(40 \mathrm{~d})$ at low temperature $\left(13^{\circ} \mathrm{C}\right)$ may offer a method of mitigating mortalities in oysters that have been exposed to an infective environment.
\end{abstract}

KEY WORDS: Juvenile oyster $\cdot$ Pathology $\cdot$ Ostreid herpesvirus $1 \cdot$ Survival $\cdot$ Temperature $\cdot$ Vibrios

\section{INTRODUCTION}

Summer mortalities of oysters have been reported for decades in many countries throughout the world, but no strict or single pathological causal factor has been found (reviewed in Samain \& McCombie 2008). These abnormal mortalities (affecting $>30 \%$ of the cultivated population) occur during summer months, when oysters are in sexual maturation. This phenomenon reflects the effects of environmental influences, reproduction, stress, genetics, pathogens and tem-

\footnotetext{
${ }^{*}$ Corresponding author. Email: fabrice.pernet@ifremer.fr
}

perature (Samain \& McCombie 2008). Summer mortalities of oysters occur when seawater temperatures exceed $19^{\circ} \mathrm{C}$, which is also the time of year when oyster energetic resources are lowest and energy demand and reproductive effort are highest (Soletchnik et al. 1997, 2006, Berthelin et al. 2000, Delaporte et al. 2006).

Since 2008, mass mortalities of young Crassostrea gigas have notably affected all rearing sites along the coasts of France where seawater temperatures reach 16 to $17^{\circ} \mathrm{C}$ (Bedier 2010, EFSA 2011). Young oysters

() The authors 2013. Open Access under Creative Commons by Attribution Licence. Use, distribution and reproduction are unrestricted. Authors and original publication must be credited. 
( $<1 \mathrm{yr}$ ) are decimated at levels ranging from 40 to $100 \%$, depending on locations and batches, whereas older animals are generally much less affected (Pernet et al. 2010, 2012, Dégremont 2011). These recent mortality events represent the most serious crisis for the French oyster industry since the introduction of C. gigas in the early 1970s. Although oyster mortalities have mostly been reported in France during this period, several cases have also been noted in Ireland, the Channel Islands and the UK (EFSA 2011, Martenot et al. 2011, Renault 2011, Peeler et al. 2012). More recently, cases have also been reported in Australia and New Zealand (Renault et al. 2012). Results of diagnostic tests show that recent mortality events in France, Ireland and the UK are associated with the detection of a particular genotype of the ostreid herpesvirus 1 (OsHV-1) named $\mu$ Var (Segarra et al. 2010).

Temperature is commonly one of the major triggering factors of disease epizootics, especially for aquatic species. In France, OsHV-1 is generally detected in dying oysters when seawater temperatures are $>16$ to $17^{\circ} \mathrm{C}$ (Pernet et al. 2012). Prior to 2008, the threshold temperature was $19^{\circ} \mathrm{C}$ (Samain \& McCombie 2008). This change to the lower temperature threshold was synchronous with the rise in frequency of OsHV-1 $\mu$ Var. Over the course of a single year, OsHV-1 is usually first detected in the south of France, where temperatures are higher than in the north, and its detection follows a temporal south-north gradient of increasing temperatures along the coast (EFSA 2011). Detection of OsHV-1 DNA and mortality in oysters generally occurs after a marked increase in mean daily seawater temperature (Garcia et al. 2011). A similar effect of temperature on OsHV-1-related mortality was reported in the field for juvenile oysters in Tomales Bay, USA (Burge et al. 2006), and under experimental conditions (Sauvage et al. 2009). The influence of temperature on OsHV-1 occurrence and virus expression has also been demonstrated for Crassostrea gigas larvae (Le Deuff et al. 1996) and is suspected for juveniles (Renault et al. 1995, Friedman et al. 2005, Burge et al. 2007, Sauvage et al. 2009).

The overall objective of the present study was to examine the effect of seawater temperature on disease transmission and subsequent mortality of oysters. In contrast to most previous studies where diseased oysters were exposed to a specific pathogen by injection or cohabitation, oysters in the present study were simply exposed to field conditions where mass mortalities of farmed and wild oysters were occurring. The advantage of this infection protocol is that exposed oysters are naturally infected in the field; therefore, if they contract a disease, then it is most probably caused by the same agents related to the mass mortality phenomenon. While OsHV-1 $\mu$ Var is considered to trigger most mass mortality phenomena in oysters (Segarra et al. 2010, Schikorski et al. 2011b, Pernet et al. 2012), other pathogens such as vibrios probably also play a role (Paillard et al. 2004, Saulnier et al. 2010, Vezzulli et al. 2010). Our infection protocol takes these into account and aims to reproduce the natural infection process occurring in the field.

The first set of experiments $\left(A_{1}\right.$ and $\left.A_{2}\right)$ was designed to specifically investigate whether mortality of healthy oysters is influenced by cohabitation with oysters previously exposed to field conditions where mortalities are occurring and, thus, presumably infected. These experiments were conducted at 13.0 and $20.6^{\circ} \mathrm{C}$, i.e. temperatures lower and higher than the generally accepted threshold values of 16 to $17^{\circ} \mathrm{C}$ above which mortalities usually occur. The second experiment (B) aimed to investigate whether disease transmission and related mortality of oysters are influenced by seawater temperature. Exposed oysters were placed in contact with naïve oysters at 8 temperatures ranging from 13.4 to $29.0^{\circ} \mathrm{C}$, and animals were regularly sampled for OsHV-1 DNA detection and total vibrio counts.

\section{MATERIALS AND METHODS}

\section{Collection and maintenance}

Wild individuals were collected in Fouras (Marennes-Oléron, France) in August 2008 and placed in mesh bags in February 2009 for transfer to Paimpol (northern Brittany, France, 48 48' 24.49" N, $\left.3^{\circ} 0^{\prime} 22.84 " \mathrm{~W}\right)$ until February 2010. Then, these animals were moved to the Ifremer grow-out farm located at Aber-Benoît (northern Brittany, France, $\left.48^{\circ} 34^{\prime} 29.976^{\prime \prime} \mathrm{N}, 4^{\circ} 36^{\prime} 18.378^{\prime \prime} \mathrm{W}\right)$. These animals were exposed to disease during the spring of 2009 and suffered ca. $75 \%$ mortality.

In April 2010 (Expt $A_{1}, A_{2}$ ) and February 2011 (Expt B), 60 individuals were transferred to the Ifremer marine station located at Argenton (Brittany, France, 48 $\left.31^{\prime} 16.320^{\prime \prime} \mathrm{N}, 4^{\circ} 46^{\prime} 01.998^{\prime \prime} \mathrm{W}\right)$ for conditioning. These animals were held in 5001 flowthrough tanks for $6 \mathrm{wk}$, with seawater at $19^{\circ} \mathrm{C}$ and enriched with a phytoplankton mixture. Seawater was treated with UV radiation and filtered at $1 \mu \mathrm{m}$. The daily mixed diet consisted of Isochrysis affinis galbana (T-ISO) and Chaetoceros gracilis (1:1 in dry weight) at 
a ration equivalent to $6 \%$ of the oyster dry weight. Once the oysters were reproductively mature, gametes from 13 males and 27 females, obtained by stripping, were mixed in a 51 jar at 50 spermatozoids oocyte $^{-1}$ on 9 June 2010 for Expt A and on 6 March 2011 for Expt B. The fertilized oocytes completed their embryonic development in $150 \mathrm{l}$ tanks filled with $1 \mu \mathrm{m}$ filtered and UV-treated seawater at $21^{\circ} \mathrm{C}$ for $48 \mathrm{~h}$. The D-larvae were then collected and reared in flowthrough rearing systems at $25^{\circ} \mathrm{C}$ (Rico-Villa et al. 2008). At the end of the pelagic phase (16 d), competent larvae were collected on a $225 \mu \mathrm{m}$ sieve and allowed to settle on cultch. Post-larvae were maintained in downwelling systems where they were continuously supplied with enriched seawater. After $10 \mathrm{~d}$, the cultchless spat were collected on $400 \mu \mathrm{m}$ mesh and reared at $25^{\circ} \mathrm{C}$ in downwellers for $90 \mathrm{~d}$. In the larval and post-larval stages, the oysters were fed the same diet as the broodstock, at a concentration of $1500 \mu^{3}$ $\mathrm{\mu l}^{-1}$ (Rico-Villa et al. 2009). Throughout this time, the oysters were free of any abnormal mortality and OsHV-1 DNA was not detected.

\section{Experimental design}

On 26 August 2010 (Expt A) and 6 July 2011 (Expt B), subsamples of juvenile oysters (ca. 2500 individuals) were transferred to a farming area located in the Bay of Brest at Pointe du Chateau $\left(48^{\circ} 20^{\prime} 06.19^{\prime \prime} \mathrm{N}, 4^{\circ} 19^{\prime} 06.37^{\prime \prime} \mathrm{W}\right)$ where mortalities were occurring among local oysters (Ifremer Observatoire Conchylicole 2010, 2011, http://wwz.ifremer. fr/observatoire_conchylicole/Resultats-nationaux/). Shell length of juvenile oysters varied between 15 and $30 \mathrm{~mm}$, average whole body wet weight was $0.3 \mathrm{~g}$ and age was $3 \mathrm{mo}$. The experimental oysters were left exposed to field conditions for $16 \mathrm{~d}$ (Expt A) and $10 \mathrm{~d}$ (Expt B), and were then transferred back to the facilities in Argenton (Fig. 1). Mean seawater temperatures in the field during this exposure were 17.1 and $18.1^{\circ} \mathrm{C}$ for Expts $\mathrm{A}$ and $\mathrm{B}$, respectively. These field-exposed oysters did not show significant mortality during the exposure periods. Subsamples of the exposed oyster batches were left in the field to examine whether they suffered mortalities later (Fig. 1).

Expt A: effect of temperature and cohabitation between field-exposed and naïve oysters on mortality

The first objective of this experiment $\left(\mathrm{A}_{1}\right)$ was to investigate whether mortality of naïve oysters (pre- sumably healthy oysters in which OsHV-1 DNA was not detected, see below for screening method) is influenced by cohabitation with oysters previously exposed to field conditions where mortalities were occurring (presumably infected), as a function of temperature. From 10 September 2010, exposed and naïve oysters were maintained separately or reared together in duplicate rectangular $23 \mathrm{l}$ plastic tanks at 13.0 and $20.6^{\circ} \mathrm{C}$ for $40 \mathrm{~d}$ (Fig. $1 \mathrm{~A}$, Expt $\mathrm{A}_{1}, 3$ treatments [exposed alone, naïve alone and cohabitation] $\times 2$ tanks $\times 2$ temperatures $=12$ experimental units). Naïve oysters maintained alone are hereafter referred to as 'control' animals, whereas naïve oysters held in cohabitation with field-exposed animals are referred to as 'challenged' individuals. Naïve oysters were previously acclimated to the chosen experimental temperatures from 26 August 2010. Each tank contained 200 oysters. In the cohabitation treatment, 100 exposed oysters were placed on one side of the tank and 100 naïve oysters ('challenged') were placed downstream, on the opposite side. Each tank was supplied with $1 \mu \mathrm{m}$ filtered seawater exposed to UV irradiation flowing at $100 \mathrm{ml} \mathrm{min}^{-1}$.

The second objective of this experiment $\left(\mathrm{A}_{2}\right)$ was to investigate whether maintaining oysters at low temperature over a long-term period influences mortality of individuals previously exposed to field conditions (presumably infected) and disease transmission to naïve oysters. After $40 \mathrm{~d}$ at $13.0^{\circ} \mathrm{C}\left(\right.$ Expt $\left.\mathrm{A}_{1}\right)$, the oysters reared in cohabitation were suddenly exposed to a temperature of $20.6^{\circ} \mathrm{C}$ (Fig. $1 \mathrm{~A}$, Expt $\mathrm{A}_{2}$ ) and maintained at that temperature for $28 \mathrm{~d}$. In parallel, some of the challenged oysters that had been grown in cohabitation were separated from the previously exposed oysters and maintained alone in separate tanks for $28 \mathrm{~d}$. Concomitantly, groups of exposed and naïve oysters that had been held alone at $13^{\circ} \mathrm{C}$ for the first $40 \mathrm{~d}$ were, respectively, left alone until the end of the experiment at $13^{\circ} \mathrm{C}$ or exposed to $20.6^{\circ} \mathrm{C}$ (Fig. $1 \mathrm{~A}$, Expt $\mathrm{A}_{2}$ ).

Live and dead animals were regularly counted, and dead animals were removed from the tanks (see Fig. 1A for details of the time frame). Due to logistic limitations, OsHV-1 analyses were conducted on selected samples only. OsHV-1 DNA detection was conducted at the start of Expt A on both exposed and naïve oysters, in duplicate samples consisting of 3 pooled individuals. Subsequently, detection of OsHV-1 was only performed on oysters grown in cohabitation at 13.0 and $20.6^{\circ} \mathrm{C}$. Three exposed and 3 naïve oysters were sampled after $3 \mathrm{~d}$ in each tank ( $\mathrm{n}=6$ individuals for each status [exposed or naïve] and temperature). Finally, analyses of OsHV-1 were 


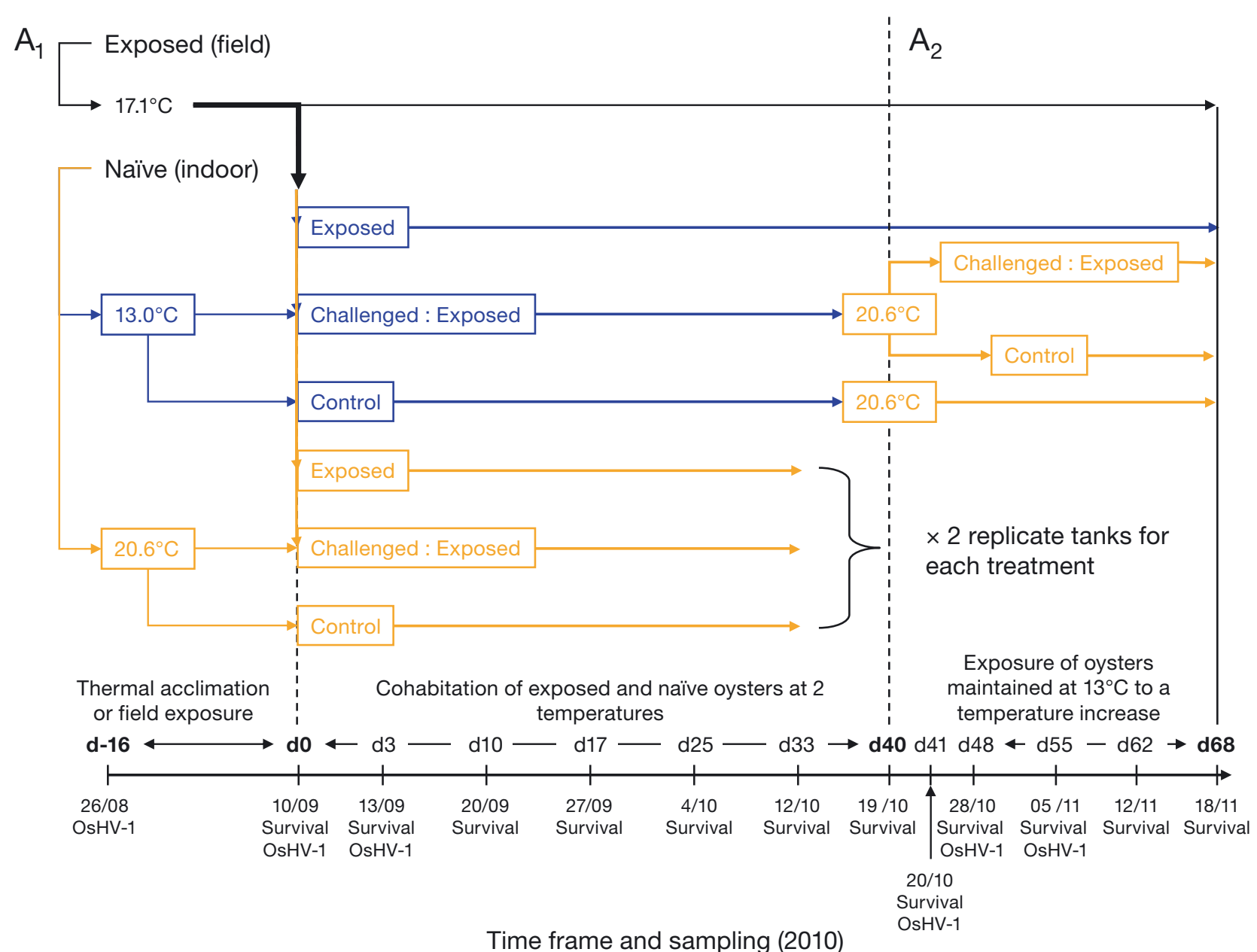

Fig. 1. Crassostrea gigas. Schema showing experimental designs. Expts $A_{1}$ and $A_{2}$ investigated whether mortality of healthy oysters (challenged) is influenced by cohabitation with oysters previously exposed to field conditions where mortalities were occurring and, thus, presumably infected. These experiments were conducted at 13.0 and $20.6^{\circ} \mathrm{C}$. Expt B aimed to investigate whether disease transmission and related mortality of oysters are influenced by seawater temperature. Exposed oysters were placed in contact with naïve oysters (challenged) at 8 temperatures ranging from 13.4 to $29.0^{\circ} \mathrm{C}$. Animals were regularly sampled for ostreid herpesvirus 1 (OsHV-1) DNA detection and total vibrio counts. Dates are dd/mm

also carried out on oysters grown in cohabitation at $13.0^{\circ} \mathrm{C}$ for the first $40 \mathrm{~d}$, and then at $20.6^{\circ} \mathrm{C}$. Five exposed and 5 naïve oysters were sampled after 41 , 48 and $55 \mathrm{~d}$ in each tank $(\mathrm{n}=10$ individual oysters for each status and date of sampling). All OsHV-1 analyses for Expt A were performed by Labofarm (Loudéac, France) using standard PCR methods (Pepin et al. 2008).

Expt B: effect of temperature on disease transmission and related mortalities

The objective of Expt B was to investigate whether disease transmission and related mortality of oysters are influenced by seawater temperature. This cohab- itation experiment was designed based on results obtained in Expt A, which showed that it was possible to transmit disease and related mortality to healthy Crassostrea gigas spat in cohabitation experiments using oysters infected by means of brief exposure to field conditions where mortalities were occurring. On 16 July 2011, these previously exposed oysters were placed randomly in duplicate rectangular 231 plastic tanks in contact with naïve oysters at 8 different temperatures $(13.4,14.4,15.4,16.2,17.5,21.9$, 26.9 and $29.0^{\circ} \mathrm{C}$ ) (Fig. 1B). Naïve oysters had been previously acclimated at the desired experimental temperature from 6 July 2011. Then, 100 exposed oysters were placed on one side of each tank, whereas another 100 naïve oysters were placed downstream, on the opposite side. Each tank was 


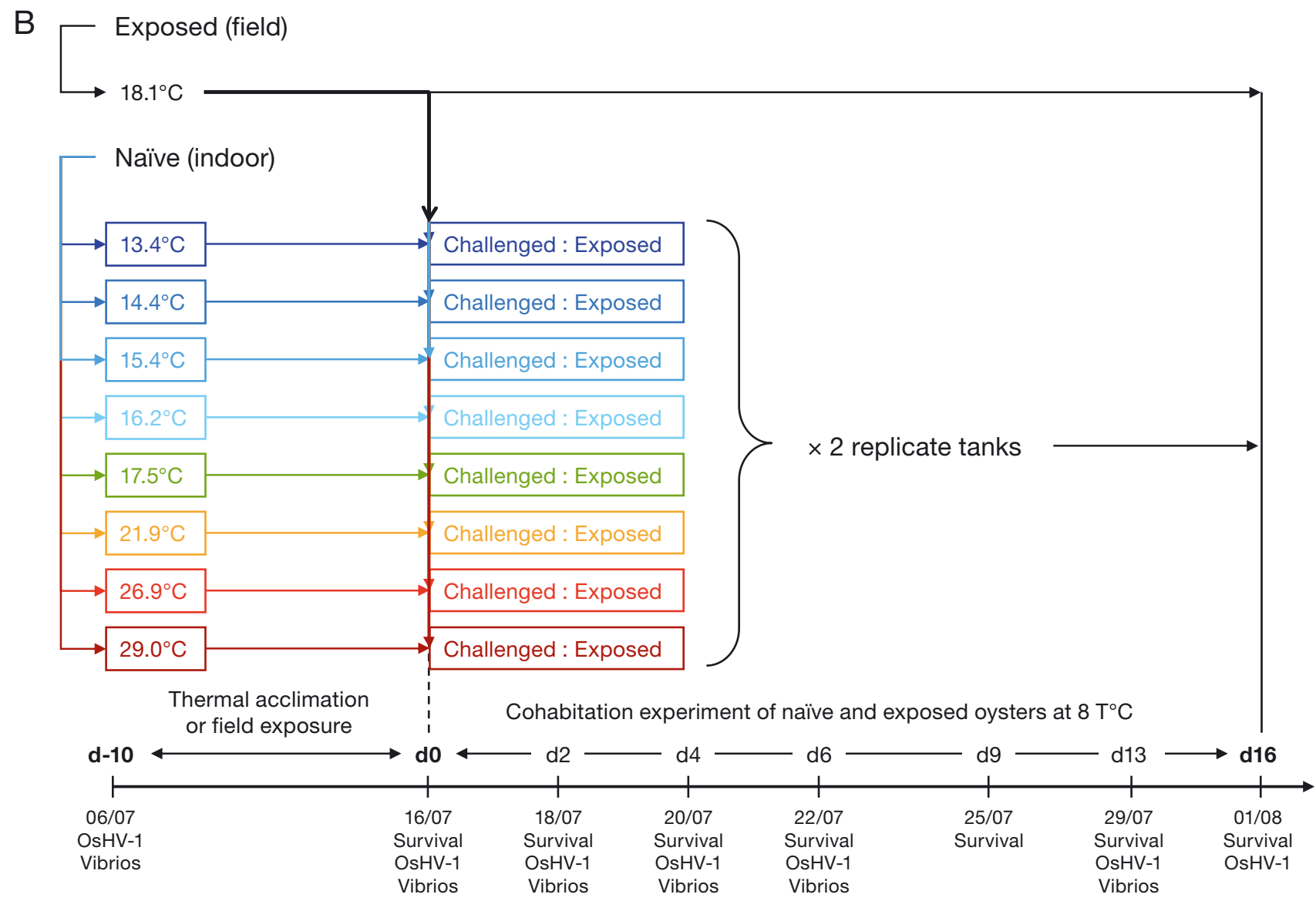

Time frame and sampling (2011)

Fig. 1 (continued)

supplied with $1 \mu \mathrm{m}$ filtered UV-irradiated seawater flowing at $100 \mathrm{ml} \mathrm{min}{ }^{-1}$. These naïve oysters were hereafter referred to as 'challenged' animals.

Live and dead animals were counted at the start of the experiment and after 2, 4, 6, 9, 13 and $16 \mathrm{~d}$ (Fig. 1B). Dead animals were removed from the tank at each count. Both exposed and challenged oysters were sampled at the start of the experiment and after $2,4,6$ and $13 \mathrm{~d}$ for OsHV-1 DNA detection and bacterial analyses $\left(\mathrm{n}=3\right.$ pooled oysters $\operatorname{tank}^{-1}$ ). For OsHV-1, an additional sampling was conducted after $16 \mathrm{~d}$.

\section{Laboratory analyses}

OsHV-1 DNA detection and bacterial analyses were conducted on 3 pooled oysters $\operatorname{tank}^{-1}(\mathrm{n}=6$ individuals from each temperature treatment on each sampling day). OsHV-1 testing and DNA extraction were performed by IDHESA Bretagne Océane (Quimper,
France), and we carried out bacterial assessments (see below). For the analyses, oyster tissue (50 to $100 \mathrm{mg}$ of flesh sample ${ }^{-1}$ ) was homogenized in sterile artificial seawater diluent with a sterile pellet-pestle for 1 min (Pepin et al. 2008, Saulnier et al. 2010).

\section{DNA quantification of herpesvirus OsHV-1}

Total DNA was then extracted from an aliquot of tissue sample using a QIAgen QIAamp tissue mini kit according to the manufacturer's protocol. The extracted DNA was stored at $-20^{\circ} \mathrm{C}$ prior to pathogen detection and quantification. The detection and quantification of OsHV-1 DNA was carried out using a previously published real-time PCR protocol (Pepin et al. 2008). Briefly, this protocol uses SYBR ${ }^{\circledR}$ Green chemistry with specific DPFor/DPRev primers targeting the region of the OsHV-1 genome predicted to encode a DNA polymerase catalytic sub- 
unit (Webb et al. 2007). The specificity and the sensitivity of the detection test using these primers were similar to those reported by Pepin et al. (2008) (data not shown). The method used in our study is the recommended method for reasons of availability, utility and diagnostic specificity and sensitivity for OsHV-1 detection (OIE 2012, www.oie.int/fileadmin/ Home/eng/Health_standards/aahm/2010/2.4.09_INF_ OSTREID_HERPES.pdf). Results were expressed as detection frequencies when oysters were sampled individually (Expts $A_{1}, A_{2}$ ) or as viral DNA copy number per milligram wet tissue when sampled oysters were pooled (Expt B).

\section{Targeted detection of OsHV-1 $\mu$ Var}

The standard real-time PCR method using SYBR ${ }^{\circledR}$ Green cannot differentiate the OsHV-1 reference from OsHV-1 $\mu$ Var. Therefore, specific primers were used to distinguish the 'reference' and the ' $\mu V{ }^{\prime}$ ' genotypes by comparison with positive controls (EFSA 2011, Appendix B of Council Regulation 175/ 2010). These complementary OsHV-1 $\mu$ Var-specific PCR analyses were performed on the samples $(n=5)$ in which OsHV-1 DNA had first been detected. These samples were (1) the experimental oysters that were left exposed to field conditions for $16 \mathrm{~d}$ (Expt A) and $10 \mathrm{~d}$ (Expt B) and those that were used for the challenge experiments $(n=2$ samples of pooled oysters). Also, complementary OsHV-1 $\mu$ Var-specific PCR analyses were performed on challenged animals at $20.6^{\circ} \mathrm{C}$ in Expt $\mathrm{A}_{1}$ after $3 \mathrm{~d}$. It is noteworthy that in 2009 the OsHV-1 $\mu$ Var had fully replaced the reference OsHV-1 genotype in seed, presenting mortality at all French oyster production sites.

\section{Quantification of vibrios}

Tissue samples diluted in sterilized seawater (1:100) were spread on marine broth medium, thiosulfate-citrate-bile salts-sucrose (TCBS) agar and CHROMagar in Petri dishes to quantify cultivable bacteria and, more specifically, vibrios. The bacteriological media used in this study were obtained from Difco Laboratories. These plates were incubated at $22.5^{\circ} \mathrm{C}$ for $48 \mathrm{~h}$ before counting the number of CFU. Only vibrios data collected on CHROMagar are presented here because CHROMagar is somewhat more specific for vibrios than is TCBS (e.g. Di Pinto et al. 2011), and a correlation with TCBS was found under the conditions used here.

\section{Statistical analyses}

Survival curves of oysters as a function of treatment (for Expt A: separate or in cohabitation), seawater temperature (2 levels for Expt A, 8 levels for Expt B) and status (previously exposed or unexposed to field conditions [naïve]) were compared using the Lifetest procedure in SAS 9.2 (SAS Institute). When differences were detected, $\chi^{2}$ comparison tests were applied to determine which treatment combinations differed significantly. A significant threshold of 0.05 was adopted for all statistical tests.

No statistical tests were performed on OsHV-1 data collected in Expts $A_{1}$ and $A_{2}$. Results concerning OsHV-1 detection were very clear, and no further statistical analysis was performed. For Expt B, 3-way split-split plot ANOVAs were conducted to determine differences in the quantity of herpesvirus OsHV-1 DNA and vibrios detected in oyster tissues, as a function of seawater temperature, status of oysters (previously exposed to field conditions or challenged) and time (day of sampling). The unit of replication was the tank in which the temperature was applied ( $\mathrm{n}=2$ for each temperature). The main plots were seawater temperature levels $(13.4,14.4,15.4$, $16.2,17.5,21.9,26.9$ and $29.0^{\circ} \mathrm{C}$ ), subplots were status levels (previously exposed and challenged) and sub-subplots were sampling time. Here we used a mixed linear model, which modeled not only the means of our data but also their variances and covariances. The need for covariance parameters arose because the experimental units on which the variables were measured were grouped into clusters and repeated measurements were taken on the same experimental unit. The 'repeated' option was applied to the term 'time' to take into account temporal dependence (SAS 9.1.3, SAS Institute).

Where differences were detected, least-squared means multiple comparison tests were used to determine which means were significantly different. When time interacted with temperature and status of oysters, regression models were used to examine the relationship between the tested variable and time for each temperature and each group of oysters. Residuals were screened for normality using the expected normal probability plot and further tested using the Shapiro-Wilk test. Data on the quantity of herpesvirus OsHV-1 DNA and CFU of cultivable bacteria and vibrios were $\log (x+1)$ transformed to obtain normality of residuals and homogeneity of variances.

Regression models were used to examine the relationships between temperature and final survival in Expt B for oysters exposed to field mortality and oys- 
ters grown in cohabitation. Regression models were also used to examine the relationships between temperature and the time needed to reach peak values of OsHV-1 DNA and vibrios in challenged oysters. All temperature treatments were confounded $(\mathrm{n}=8$ temperatures). Finally, regression models were also used to investigate the synchrony between the onset of oyster mortality and outbreaks of OsHV-1 and vibriosis in challenged oysters. In particular, the time required to observe at least 5\% mortality was correlated with the time required to reach $10^{4}$ DNA copies of OsHV-1 per mg or $10^{4} \mathrm{CFU}$ of vibrios per $100 \mathrm{mg}$ in challenged oysters. The threshold was set at $10^{4}$ DNA copies of OsHV-1 per mg because this is the value above which OsHV-1 is considered to be involved in mortality (Oden et al. 2011, Schikorski et al. 2011a). Additionally, $10^{4} \mathrm{CFU}$ of vibrios corresponded to the maximum values that were found in challenged oysters (see 'Results: Vibrios'). All temperature treatments were considered together $(\mathrm{n}=16$ tanks, 8 temperatures $\times 2$ replicate tanks). Analyses were carried out using SAS 9.2 (SAS Institute).

\section{RESULTS}

\section{Survival}

Survival of the oysters that had been left for a period at the field site in the Bay of Brest from 26 August 2010 (Expt $A_{1}$ and $A_{2}$ ) or 6 July 2011 (Expt B) was 32.0 and $50.0 \%$, respectively, 16 and $10 \mathrm{~d}$ after the start of each of the laboratory experiments (d0; Fig. 1).

In Expt $\mathrm{A}_{1}$, survival of oysters maintained indoors at $13.0^{\circ} \mathrm{C}$ for $40 \mathrm{~d}$ was $98.2 \%$, irrespective of treatment (exposed alone, control alone or cohabitation of exposed and naïve animals; Fig. 2A,B). Similarly, survival of control oysters at $20.6^{\circ} \mathrm{C}$ was $99.6 \%$ (Fig. 2B). In contrast, survival of field-exposed oysters maintained at $20.6^{\circ} \mathrm{C}$ decreased rapidly as a function of time, reaching 10.2 and $24.8 \%$ after $40 \mathrm{~d}$ in cohabitation and separate (alone) conditions, respectively (Fig. 2A). Also, survival of challenged oysters at $20.6^{\circ} \mathrm{C}$ decreased moderately, reaching $71.2 \%$ after $40 \mathrm{~d}$ (Fig. 2B). Therefore, mortalities were recorded when seawater temperature was $20.6^{\circ} \mathrm{C}$ in oysters previously exposed to field conditions where mortalities were occurring and, to a lesser extent, in challenged oysters. During Expt $\mathrm{A}_{2}$, no mortality was recorded in any treatment.

In Expt B, survival of oysters that had previously been exposed to field conditions was generally half
$(37.9 \%)$ that of challenged animals, irrespective of temperature $(79.1 \%$; log-rank test, $p<0.001$; Fig. 2C,D). Temperature influenced survival of both exposed and challenged oysters (log-rank tests, p < 0.001; Fig. 2C,D). In previously exposed oysters, the highest rate of decrease in survival and the lowest final survival (at the end of the experimental period) were observed when seawater temperatures ranged between 21.9 and $29.0^{\circ} \mathrm{C}$ (Fig. 2C,E). It is noteworthy that survival was only $50.2 \%$ in exposed oysters maintained between 21.9 and $29.0^{\circ} \mathrm{C}$ for 2 consecutive days, compared with the $93.5 \%$ recorded at 13.4 to $17.5^{\circ} \mathrm{C}$ (Fig. 2C). Final survival of previously exposed oysters decreased as a function of seawater temperature, following a quadratic relationship (survival $_{16 \mathrm{~d}}=0.0014 \mathrm{Temp}^{2}-$ 0.070Temp + 1.180; $\mathrm{r}^{2}=0.85, \mathrm{p}=0.007$; Fig. 2E). In contrast, in challenged oysters, the highest rate of decrease in survival and the lowest final survival were observed when seawater temperatures ranged between 16.2 and $21.9^{\circ} \mathrm{C}$ (Fig. 2D,E). As observed in previously exposed oysters, final survival of challenged oysters grown in cohabitation with exposed animals decreased as a function of seawater temperature, following a quadratic relationship (survival $_{16 \mathrm{~d}}=0.0049 \mathrm{Temp}^{2}-0.201 \mathrm{Temp}+2.780 ; \mathrm{r}^{2}=$ 0.88, $p=0.005$; Fig. 2E). It is, however, noteworthy that at $13.4^{\circ} \mathrm{C}$, the lowest temperature tested in this study, final survival of challenged oysters was $97.8 \%$ compared with only $48.0 \%$ in exposed animals (Fig. 2E).

\section{OsHV-1}

At the start of Expts A and B, levels of OsHV-1 DNA in oysters previously exposed to field conditions in the Bay of Brest were $1.9 \times 10^{8}$ and $1.7 \times$ $10^{8}$ copies $\mathrm{mg}^{-1}$, respectively, which are higher than the threshold values of $10^{4}$ DNA copies $\mathrm{mg}^{-1}$ at which OsHV-1 is considered to be involved in mortality (Oden et al. 2011, Schikorski et al. 2011a, Pernet et al. 2012). In contrast, OsHV-1 DNA was not detected in naïve oysters at these times. Therefore, in both experiments, oysters became infected by OsHV-1 by means of brief exposure to field conditions for 10 or $16 \mathrm{~d}$ in areas where mortalities were occurring, whereas OsHV-1 DNA remained undetected in naïve oysters. The oysters exposed to field conditions and further used in Expts A and B were infected by OsHV-1. OsHV-1 $\mu$ Var-specific PCR analyses performed on these samples detected OsHV-1 $\mu$ Var genotype only. 

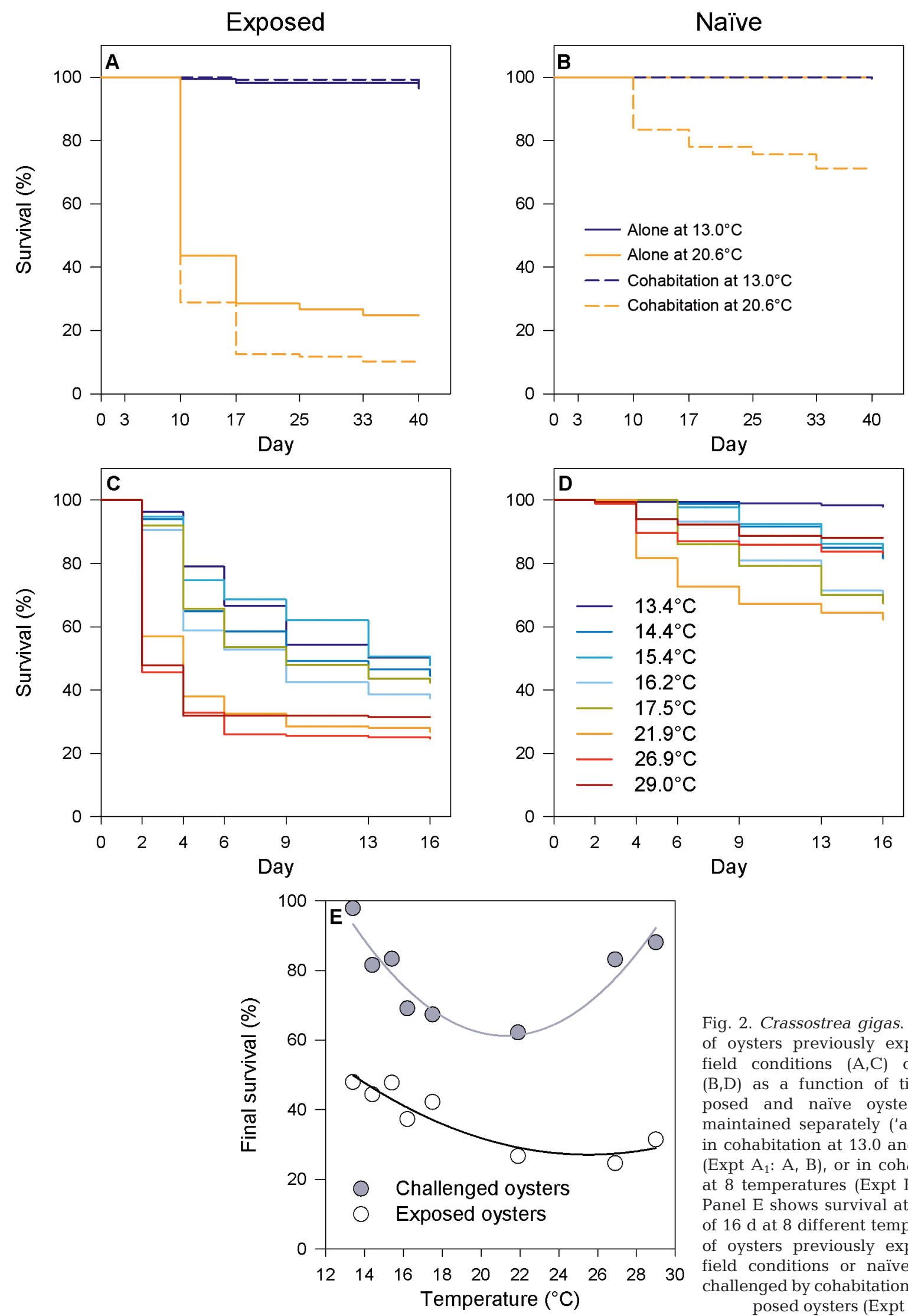

Fig. 2. Crassostrea gigas. Survival of oysters previously exposed to field conditions $(\mathrm{A}, \mathrm{C})$ or naïve $(B, D)$ as a function of time. Exposed and naïve oysters were maintained separately ('alone') or in cohabitation at 13.0 and $20.6^{\circ} \mathrm{C}$ (Expt $\left.A_{1}: A, B\right)$, or in cohabitation at 8 temperatures (Expt B: C, D). Panel E shows survival at the end of $16 \mathrm{~d}$ at 8 different temperatures of oysters previously exposed to field conditions or naïve oysters challenged by cohabitation with exposed oysters (Expt B) 
In Expt A, OsHV-1 DNA became undetectable in previously exposed oysters after only $3 \mathrm{~d}$ at $13.0^{\circ} \mathrm{C}(0$ out of 6 individuals sampled in each cohabitation tank). Meanwhile, OsHV-1 detection frequency was $100 \%$ in exposed oysters at $20.6^{\circ} \mathrm{C}$ ( 6 out of 6 individuals sampled in each cohabitation tank) and $50 \%$ in challenged oysters at $20.6^{\circ} \mathrm{C}$ (3 out of 6 individual oysters sampled in each cohabitation tank). Again, OsHV-1 $\mu$ Var-specific PCR analyses performed on these samples only showed OsHV-1 $\mu$ Var.

During Expt $\mathrm{A}_{2}$, OsHV-1 DNA remained undetected in oysters in cohabitation that had been initially maintained at $13.0^{\circ} \mathrm{C}$ and then suddenly exposed to $20.6^{\circ} \mathrm{C}$ ( 0 out of 40 individual oysters [both previously exposed and challenged] sampled in each cohabitation tank after 41, 47 and 55 d).

In Expt B, levels of OsHV-1 DNA in oysters varied as a function of the interaction of temperature, oyster status (exposed vs. challenged) and sampling time (Table 1, Fig. 3). In exposed oysters, OsHV-1 DNA decreased gradually as a function of time, irrespective of seawater temperature. At the end of the experimental period, the level of OsHV-1 DNA was $\sim 6.1 \times 10^{4}$ copies $\mathrm{mg}^{-1}$ in exposed oysters at temperatures ranging from 13.4 to $17.5^{\circ} \mathrm{C}$ (Fig. $3 \mathrm{~A}$ to $\mathrm{E}$ ), but OsHV-1 DNA was below $10^{2}$ copies $\mathrm{mg}^{-1}$ in exposed oysters at temperatures $\geq 21.9^{\circ} \mathrm{C}$ (Fig. $3 \mathrm{~F}$ to $\mathrm{H})$. Therefore, it seems that increasing temperature enhanced the rate of decrease in OsHV-1 DNA detected in previously exposed oysters.

Levels of OsHV-1 DNA in challenged oysters increased until they attained similar values to those observed in the previously exposed oysters, and decreased thereafter irrespective of temperature (Fig. 3). OsHV-1 DNA concentrations in these challenged oysters peaked 2 to $13 \mathrm{~d}$ after contact with exposed animals. Interestingly, the time until the peak in OsHV-1 DNA occurred was negatively correlated with seawater temperature: time until peak $(\mathrm{d})=$ 678.2Temp ${ }^{-1.73} ; \mathrm{r}^{2}=0.68, \mathrm{n}=8, \mathrm{p}=0.012$. Maximum OsHV-1 DNA concentrations in challenged oysters were similar in the temperature range between 16.2 and $26.9^{\circ} \mathrm{C}$. However, maximum OsHV-1 DNA concentration in challenged oysters held at $29^{\circ} \mathrm{C}$ (the lowest value) was half that of animals held at $16.2^{\circ} \mathrm{C}$ (the highest value; Fig. 3). It is however noteworthy that there was no correlation between maximum OsHV-1 DNA concentration in challenged oysters and seawater temperature (data not shown).

Finally, the onset of mortality, expressed as the time elapsed before at least $5 \%$ mortality was observed, was not correlated with the time required to reach $10^{4}$ copies of OsHV-1 DNA $\mathrm{mg}^{-1}$ in challenged oysters (data not shown). In 13 out of 16 tanks, it took $<2$ d to attain $10^{4}$ copies $\mathrm{mg}^{-1}$ of OsHV-1 DNA in challenged oysters.
Table 1. Crassostrea gigas. Expt B. Results of the 3-way split-split plot ANOVAs examining the effects of 8 temperatures (Temp) ranging from 13.4 to $29.0^{\circ} \mathrm{C}$, oyster status (S: previously exposed or unexposed to field conditions [naïve]) and time on quantity of herpesvirus OsHV-1 DNA and CFU of vibrios detected in oyster tissues. All data were $\log (x+1)$ transformed. Error A: Tank(Temp); Error B: S $\times$ Tank(Temp); Error C: Time $\times$ Tank(Temp), df $=32$ or 24; $\mathrm{S} \times$ Time $\times$ Tank(Temp), $\mathrm{df}=32$ or 24 . Temperatures tested were 13.4, 14.4, $15.4,16.2,17.5,21.9,26.9$ and $29.0^{\circ} \mathrm{C}$. Oysters exposed to field conditions for $10 \mathrm{~d}$ were placed in contact with naïve animals in duplicate tanks for each temperature. OsHV-1 DNA detection and vibrio counts in oyster tissues were performed at the start of the experiment (data not included in mixed model ANOVAs) and after 2, 4,6 and $13 \mathrm{~d}$. For OsHV-1, an additional measurement was conducted after $16 \mathrm{~d}$. Significant $\mathrm{p}$-values $(\mathrm{p}<0.05)$ are in bold

\begin{tabular}{|lrrrrrrr|}
\hline \multirow{2}{*}{ Sources of variation } & \multicolumn{3}{c}{ OsHV-1 DNA } & \multicolumn{3}{c|}{ Vibrios (CFU) } \\
& df & $F$ & $\mathrm{p}$ & df & $F$ & $\mathrm{p}$ \\
\hline Temp & 7 & 3.32 & 0.057 & 7 & 1.00 & 0.495 \\
Error A & 8 & & & 8 & & \\
S & 1 & 9.05 & $\mathbf{0 . 0 1 7}$ & 1 & 19.38 & $\mathbf{0 . 0 0 2}$ \\
Temp $\times$ S & 7 & 0.95 & 0.522 & 7 & 0.48 & 0.824 \\
Error B & 8 & & & 8 & & \\
Time & 4 & 31.56 & $<\mathbf{0 . 0 0 1}$ & 3 & 15.05 & $<\mathbf{0 . 0 0 1}$ \\
Temp $\times$ Time & 28 & 1.40 & 0.133 & 21 & 4.15 & $<\mathbf{0 . 0 0 1}$ \\
S $\times$ Time & 4 & 1.62 & 0.179 & 3 & 2.96 & $\mathbf{0 . 0 4 2}$ \\
Temp $\times$ S $\times$ Time & 28 & 2.32 & $\mathbf{0 . 0 0 3}$ & 21 & 2.05 & $\mathbf{0 . 0 2 0}$ \\
Error C & 64 & & & 48 & & \\
\hline
\end{tabular}

\section{Vibrios}

At the start of Expt B, the number of vibrio CFU detected on CHROMagar in oysters previously exposed to field conditions in the Bay of Brest was $\sim 70$ times higher than in naïve oysters (Fig. $4 ; \mathrm{p}=0.019$ ). As the experiment went on though, the number of vibrio CFU detected in oyster tissues varied as a function of the interaction of temperature, oyster status and sampling time (Table 1, Fig. 4). In previously exposed oysters, the number of vibrio CFU varied as a function of time and temperature, but no consistent pattern emerged (Fig. 4). Overall, the number of vibrio CFU per $100 \mathrm{mg}$ oyster flesh in previously exposed oysters varied from $1.9 \times 10^{3}$ (after $13 \mathrm{~d}$ at 14.4 and $15.4^{\circ} \mathrm{C}$ ) to $1.2 \times 10^{5}$ after $6 \mathrm{~d}$ at $14.4^{\circ} \mathrm{C}$. In contrast to OsHV-1, the number of vibrio CFU in oysters previously ex- 

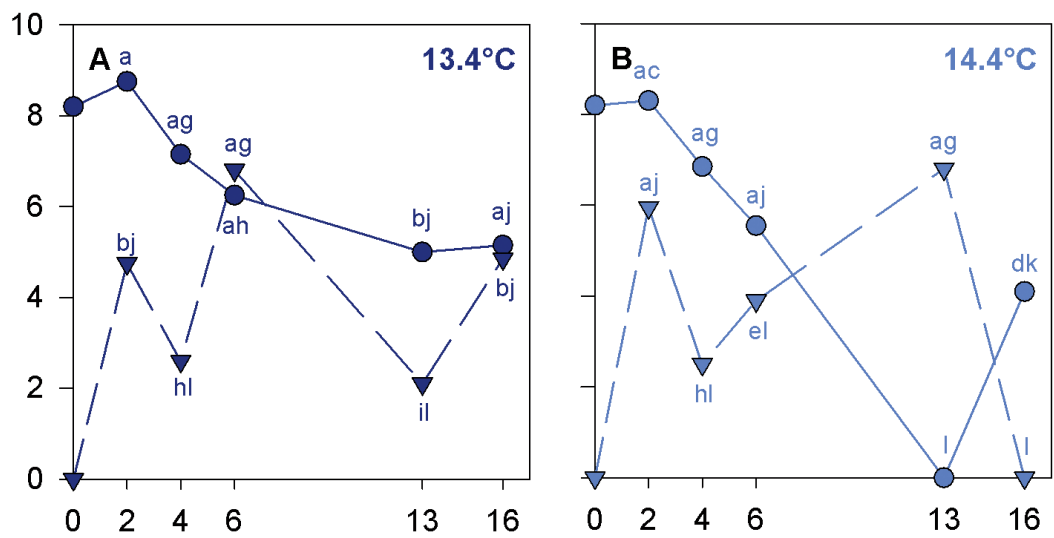

Fig. 3. Crassostrea gigas. Temporal variations in herpesvirus OsHV-1 DNA, detected in oysters previously exposed to field conditions (exposed, O) or naïve (challenged, $\nabla$ ), maintained at 8 different temperatures (Expt B). Different letters indicate significant differences between means, calculated by a mixed linear model. SEM used by the model is shown in $(\mathrm{H})$

posed to field conditions did not decrease with time (regression analyses between the number of vibrio CFU and time for each temperature and group of oysters, p > 0.075; Fig. 4).

As with the virus, the number of vibrio CFU in challenged oysters increased markedly until it attained similar values to those observed in previously exposed oysters; these results were similar among the 8 temperatures tested in Expt B. The number of vibrio CFU in challenged oysters peaked 2 to $6 \mathrm{~d}$ after contact with exposed animals. Interestingly, time until the peak was reached was $6 \mathrm{~d}$ at temperatures ranging between 13.4 and $17.5^{\circ} \mathrm{C}$ compared with only $4 \mathrm{~d}$ at $21.9^{\circ} \mathrm{C}$ and $2 \mathrm{~d}$ when temperature was 26.9 or $29^{\circ} \mathrm{C}$. Therefore, time until the peak in vibrio CFU number was negatively correlated with seawater temperature (time until peak $[\mathrm{d}]=-0.302 \mathrm{Temp}+10.6 ; \mathrm{r}^{2}=0.95$, $\mathrm{n}=8, \mathrm{p}<0.001)$.

The onset of mortality, as expressed by the time elapsed before at least $5 \%$ mortality occurred, was significantly correlated with the time required to attain $10^{4} \mathrm{CFU}$ of vibrios per $100 \mathrm{mg}$ oyster flesh in challenged oysters (Fig. 5). The relationship was linear, the slope was not significantly different from 1.0, and the constant was 2.0. This means that the onset of mortality followed the outbreak of vibriosis by $2 \mathrm{~d}$ and that a delay of $1 \mathrm{~d}$ in the vibriosis outbreak led to a delay of $1 \mathrm{~d}$ in mortality.

It is noteworthy that at 13.4, 14.4 and $29.0^{\circ} \mathrm{C}$, OsHV-1 and vibrio numbers peaked at roughly the same time (after 6 to $13 \mathrm{~d}$ at low temperatures, 

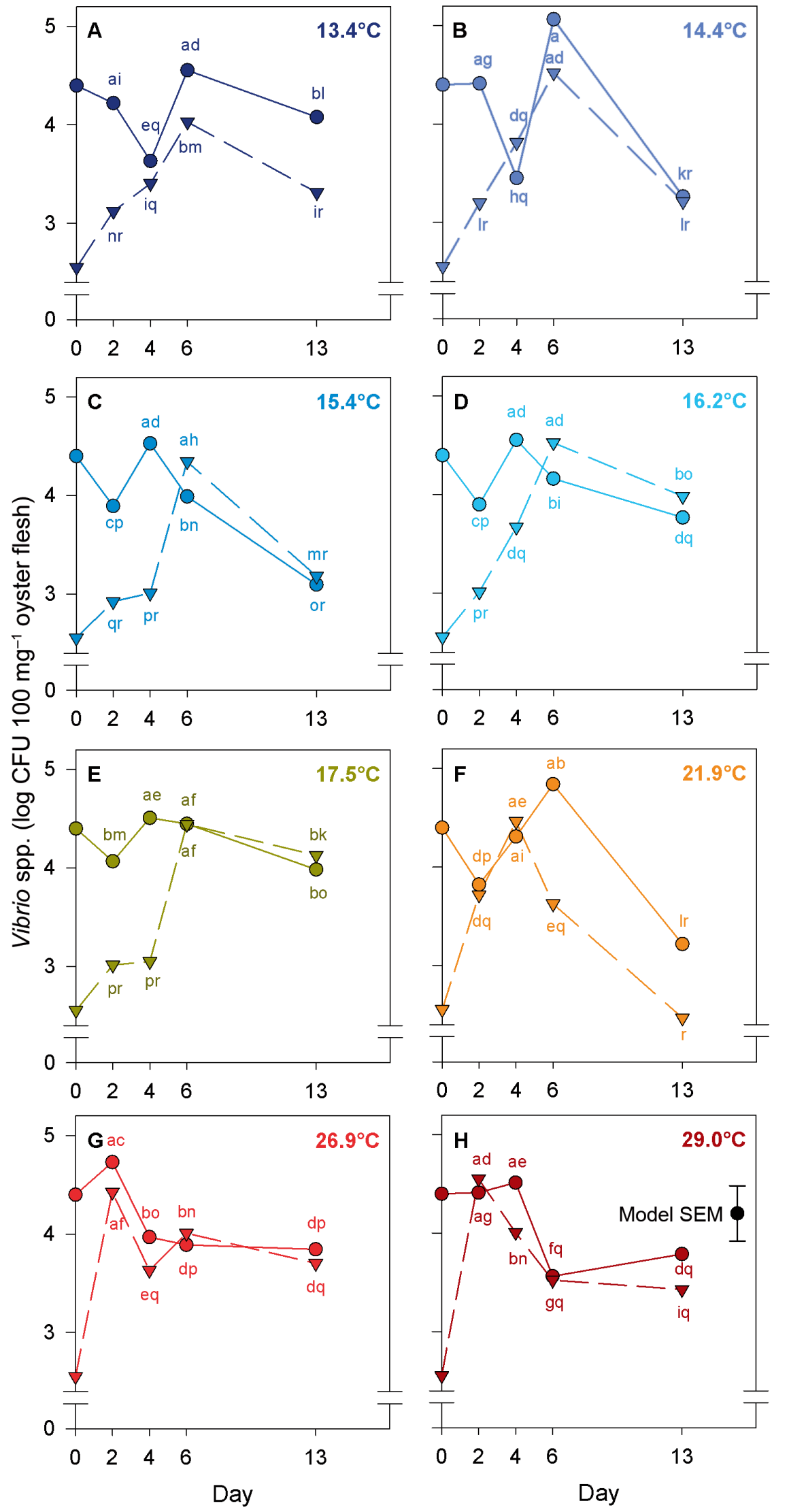

Fig. 4. Crassostrea gigas. Temporal variations in vibrio colonies plated on CHROMagar, detected in oysters either previously exposed to field conditions (exposed, 0 ) or naïve (challenged, $\nabla$ ), maintained at 8 different temperatures (Expt B). Different letters indicate significant differences between means, calculated by a mixed linear model. SEM used by the model is shown in $(\mathrm{H})$

after only $2 \mathrm{~d}$ at $29^{\circ} \mathrm{C}$ ) in challenged oysters. In contrast, OsHV-1 numbers peaked before vibrio numbers in challenged oysters when temperatures were between 16.2 and $26.0^{\circ} \mathrm{C}$.

\section{DISCUSSION}

\section{Field infection}

Pacific oysters that had been bred and reared under controlled conditions and then transferred for at least $10 \mathrm{~d}$ to a farming area where mortalities were occurring among surrounding farmed oysters became positive for detection of OsHV-1 DNA $\mu$ Var (Expts A and B) and contained high loads of vibrios (Expt B). As a result, groups of these 'exposed' animals suffered high mortalities and transmitted the disease to challenged oysters under controlled conditions.

Our study suggests that healthy oysters put in cohabitation with oysters that have high levels of OsHV-I DNA $\mu$ Var and vibrios became infected by these pathogens, as previously reported in other experiments with OsHV-1 (Schikorski et al. 2011b) or vibriosis (De Decker \& Saulnier 2011). However, in contrast to these other studies, our diseased oysters were not injected with a specific pathogen, but were instead exposed to field conditions in which mortality was occurring. The advantage of our protocol is that we avoided high-dose intramuscular injection of pathogens, which may short-circuit some potentially important lines of defense and disturb normal host immune response 


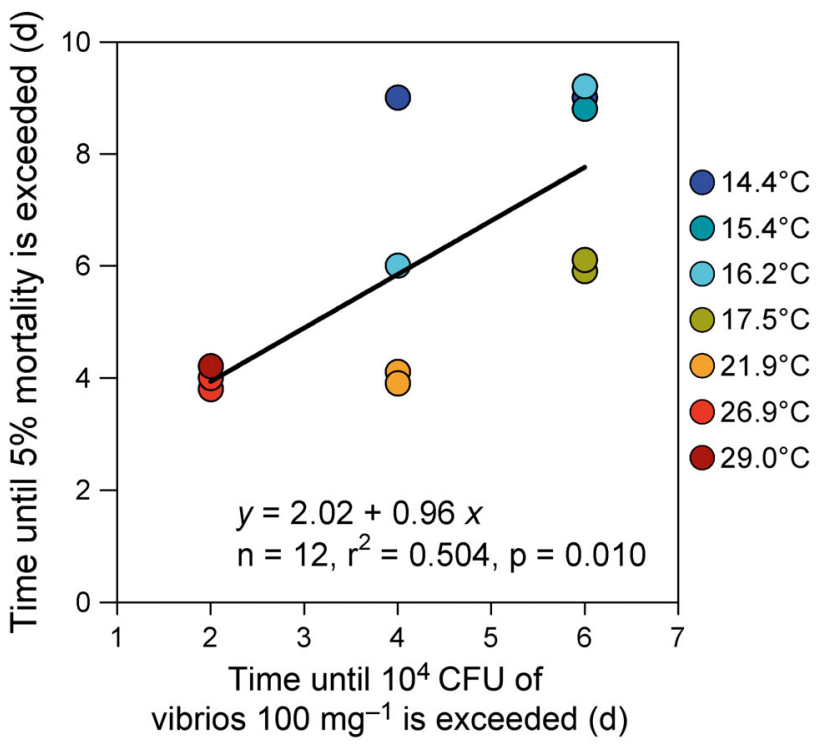

Fig. 5. Crassostrea gigas. Relationship between the number of days required to observe at least $5 \%$ mortality and the number of days required to reach $10^{4} \mathrm{CFU}$ of vibrios per $100 \mathrm{mg}$ oyster flesh in naïve oysters maintained in cohabitation with exposed animals. All temperature treatments were combined $(\mathrm{n}=12$ observations: 8 temperatures $\times 2$ replicate tanks with 4 missing combinations where mortalities were $<5 \%$ )

against invaders (De Decker \& Saulnier 2011). Exposed oysters were naturally infected in the field, and the disease they contracted is clearly the one related to the mass mortality phenomenon that occurred in the field. However, the limitation of our method is that we cannot ascertain whether the observed effect of temperature on survival of exposed oysters and oysters that had been kept in cohabitation with them is associated with a sole pathogen, such as OsHV-1 $\mu$ Var, because other pathogens (including virulent vibrios) may also have been contracted.

\section{Horizontal transmission of disease and related mortality}

Challenged oysters became infected by OsHV-1 $\mu \mathrm{Var}$ and showed significant mortality when seawater temperatures were $>13.4^{\circ} \mathrm{C}$. Similarly, Schikorski et al. (2011a) showed that it is possible to transmit OsHV-1 to healthy Crassostrea gigas juveniles in cohabitation experiments using oysters experimentally infected by intramuscular injection of an OsHV-1 suspension. Mortality and detection of OsHV-1 DNA in oysters maintained in the Thau lagoon, but outside the farming area, was sporadic and coincided with currents coming from the farming area where mortality was occurring and OsHV-1
DNA was detected (Pernet et al. 2012). Together, these results suggest that horizontal transmission of OsHV-1 particles occurs from infected oysters toward healthy animals and coincides with mortality events both in laboratory and field conditions.

Vibrio levels in challenged oysters roughly doubled until they reached values similar to those of previously exposed animals after only 2 to $6 \mathrm{~d}$ (Expt B). Evidence of successful transmission of vibriosis in cohabitation experiments with injected oysters was recently reported in Crassostrea gigas (De Decker \& Saulnier 2011, De Decker et al. 2011). In our study, the timing of the onset of mortality events varied as a function of the timing of the outbreak of vibriosis. It is therefore possible that pathogenic strains of vibrios are involved in triggering oyster mortality in the field. For instance, in the Thau lagoon, mortalities always coincided with elevated detection frequency and quantity of OsHV-1 DNA and Vibrio splendidus in oysters, thus suggesting that both these pathogens are involved in triggering the mass mortality phenomenon (Pernet et al. 2012). Laboratory experiments have shown that $V$. splendidus alone can cause death in oysters (e.g. De Decker et al. 2011). Although the effect of co-infection by OsHV-1 and vibrios remains to be further investigated, these pathogens might have synergistic effects.

Survival of oysters previously exposed to field conditions in the Bay of Brest was 2 (Expt B) to 7 times (Expt A) lower than that of challenged animals. Similarly, Schikorski et al. (2011a) showed that survival of oysters experimentally infected by intramuscular injection of OsHV-1 was only $~ 10 \%$ compared with $\sim 50 \%$ in animals that had cohabited with them at $22^{\circ} \mathrm{C}$. These authors hypothesized that differences in susceptibility among injected animals and those put in cohabitation with them could primarily be explained by the different routes of infection. Indeed, it is likely that some cohabitated oysters had not been exposed to OsHV-1, whereas oysters directly injected with the infectious virus suspension in the muscle are necessarily infected by this virus (Schikorski et al. 2011a). Alternatively, it was suggested that effective infection also depends on the quantity of viral particles in contact with oysters (Schikorski et al. 2011a). In our study, oysters were experimentally infected by means of exposure to field conditions where mortalities were occurring. Therefore, the lower survival of oysters previously exposed to field conditions compared with the survival of challenged oysters might reflect that there was a higher level of viral particles in contact with oysters in the field compared with that found in laboratory conditions. 


\section{Effect of temperature on disease and related mortality}

This study clearly shows that seawater temperature influences mortality among previously 'exposed' oysters as well as disease transmission to cohabitating healthy animals. The influence of temperature on OsHV-1 occurrence and virus expression has previously been demonstrated for Crassostrea gigas larvae (Le Deuff et al. 1996) and suggested for juveniles (Renault et al. 1995, Friedman et al. 2005, Burge et al. 2007, Sauvage et al. 2009). However, to our knowledge, the effect of low temperature (i.e. $<13^{\circ} \mathrm{C}$ ) has never been studied.

\section{Effect of low temperature $\left(\leq 13.4^{\circ} \mathrm{C}\right)$}

Oysters previously exposed to field conditions in the Bay of Brest, which were characterized by high levels of OsHV-1 $\mu$ Var DNA, subsequently showed high mortalities in the laboratory when seawater temperatures were $\geq 13.4^{\circ} \mathrm{C}$ (Expts A and B). However, at $13.0^{\circ} \mathrm{C}$, survival of these exposed oysters was 96.6\%, and OsHV-1 DNA was not detected after only $3 \mathrm{~d}$ in Expt $\mathrm{A}_{1}$. Additionally, when oysters of this same treatment were exposed to thermal elevation up to $20.6^{\circ} \mathrm{C}$ after $40 \mathrm{~d}$ at $13.0^{\circ} \mathrm{C}$, survivors of the first period showed no further mortality before the end of Expt $\mathrm{A}_{2}$ (Day 68) and OsHV-1 DNA remained undetected. All together, these results suggest that infection was not necessarily irreversible, particularly when seawater temperature was reduced to $\sim 13.0^{\circ} \mathrm{C}$.

Survival of oysters previously exposed to field conditions during Expt B was $48 \%$ at $13.4^{\circ} \mathrm{C}$, compared with $100 \%$ at $13.0^{\circ} \mathrm{C}$ in Expt $\mathrm{A}$ and coincided with the detection of high levels of OsHV-1 DNA. Therefore, it is likely that another confounding factor interacted with temperature in its effect on this disease and the subsequent mortality. It is very possible that the prevalence of the disease in oysters transferred to the field between 6 and 16 July 2011 (Expt B) was higher than that of animals exposed between $26 \mathrm{Au}$ gust and 10 September 2010 (Expt A). Nevertheless, the effect of low temperatures on disease outbreak and subsequent mortalities of oysters previously exposed to field conditions needs further clarification.

Challenged oysters showed no mortality in our laboratory conditions when seawater temperatures were $\leq 13.4^{\circ} \mathrm{C}(100.0$ and $97.8 \%$ survival in Expts $A$ and $\mathrm{B}$, respectively), and OsHV-1 DNA was not detected in oyster tissues sampled during Expt A. Additionally, when exposed to a thermal increase up to $20.6^{\circ} \mathrm{C}$ after $40 \mathrm{~d}$ at $13.0^{\circ} \mathrm{C}$, challenged and control oysters showed no mortality before the end of the experiment and OsHV-1 DNA was not detected $\left(\right.$ Expt $\left.A_{2}\right)$. These results suggest that disease and subsequent mortalities were not transmitted from exposed to challenged oysters when seawater temperature was $13.0^{\circ} \mathrm{C}$.

Although challenged oysters exhibited no mortality at low temperatures $\left(\leq 13.4^{\circ} \mathrm{C}\right)$ in either Expt A or B, OsHV-1 DNA was detected at high copy numbers in oysters from Expt B ( $>10^{6}$ DNA copies $\left.\mathrm{mg}^{-1}\right)$ but not from Expt A. Therefore, it seems that high quantities of OsHV-1 DNA do not necessarily lead to high mortality rate in oysters, as previously reported in oysters selected for improved survival to summer mortality (Dégremont 2011) and in animals cemented onto ropes at low density (Pernet et al. 2012). Additionally, this result suggests that OsHV-1 was transmitted from exposed to challenged oysters at $13.4^{\circ} \mathrm{C}$. However, it is likely that the virus was not pathogenic to these animals at low temperatures, even though OsHV-1 DNA was detected in their tissues. Indeed, PCR used to quantify OsHV-1 DNA did not specify whether the copies of viral DNA corresponded to infective viruses (enveloped virus particles), which are necessary to initiate the viral infection in host cells (Lyman \& Enquist 2009). Finally, it is possible that conditions in Expt A were somewhat different from those in Expt B as a result of one or more uncontrolled parameters (i.e. prevalence of diseased animals after field exposure), which led to large differences in OsHV-1 detection in oyster tissues.

From a practical standpoint, this study showed that oysters previously infected with OsHV-1, maintained at $13.0^{\circ} \mathrm{C}$ for $40 \mathrm{~d}$, exhibited a marked reduction in the viral DNA, showed no mortality and did not seem to transmit the virus to healthy oysters. Also, when these cold-acclimated and previously exposed oysters were reared for a further period at $20.6^{\circ} \mathrm{C}$ in laboratory conditions, OsHV-1 DNA remained undetected, the oysters exhibited no mortality and the disease was not transmitted to healthy cohabiting animals. Therefore, long-term holding at a low temperature $\left(13^{\circ} \mathrm{C}\right)$ may offer a means for mitigating oyster mortality and the spread of the related disease. The long-term survival of these cold-acclimated, previously infected oysters needs to be further evaluated, notably in the field where mortalities occurred, as it is possible that they are still susceptible to the disease. Although both experiments showed a positive effect of low temperatures on the survival of healthy and infected oysters in cohabitation, variation was high among the infected batches (100 vs. 
$48 \%$ survival in Expts A and B, respectively). Finally, this cold-acclimation protocol will need fine-tuning and validation at a larger scale.

\section{Relationship between temperature and mortalities}

Final survival of previously field-exposed oysters decreased with increasing seawater temperature, but reached a plateau between 21.9 and $29.0^{\circ} \mathrm{C}$ (Expt B). Although our study is the first to test a wide range of seawater temperatures on disease expression and related mortality of oysters, a positive effect of high temperatures on OsHV-1 infection and oyster mortality has previously been suggested (Le Deuff et al. 1996, Sauvage et al. 2009). High temperature was reported to promote early proliferation of OsHV-1 particles in association with high and sudden mortalities in Crassostrea gigas larvae (Le Deuff et al. 1996); it was therefore suggested that viral replication might be faster at 25 to $26^{\circ} \mathrm{C}$ than at 22 to $23^{\circ} \mathrm{C}$.

Survival of challenged oysters decreased as seawater temperatures rose, up to $16.2^{\circ} \mathrm{C}$, where it remained at a plateau until $21.9^{\circ} \mathrm{C}$, above which it increased. Therefore, the optimal temperature range for disease transmission was between 16.2 and $21.9^{\circ} \mathrm{C}$. This is in agreement with the fact that mass mortalities of 1-yr-old oysters usually start along the coasts of France when seawater temperature reaches $16^{\circ} \mathrm{C}$ during spring (Bedier 2010, Pernet et al. 2012). Also, the fact that mortality of challenged oysters decreased at high temperatures $\left(>21.9^{\circ} \mathrm{C}\right)$ is in good agreement with recent field experiments conducted in the southern part of France, which showed that no mortality occurred in young oysters reared at temperatures $>24^{\circ} \mathrm{C}$ (Bouquet et al. 2011, Pernet et al. 2012).

In our study, oysters in cohabitation suffered significant mortalities when seawater temperatures were 26.9 and $29.0^{\circ} \mathrm{C}$, whereas no mortality occurred in young oysters held at temperatures $>24^{\circ} \mathrm{C}$ in the Thau lagoon (Pernet et al. 2012). Such a discrepancy between laboratory and field experiments may result from the confounding effects of factors other than temperature. Experimental conditions at the marine station might be more hostile for the young oysters already exposed to disease in the field than for those that remained in the field at the same time. Indeed, survival of oysters exposed to field conditions in the Bay of Brest from 4 July 2011, and brought back to the marine station at $21^{\circ} \mathrm{C}$ after $12 \mathrm{~d}$, was markedly lower (only $29 \%$ on 25 July 2011) than that of control animals left in the field, where survival was $56 \%$ on 25 July 2011 (B. Petton et al. unpubl.).
The hydrodynamic connectivity between infected and healthy animals, which is a major driver of disease epidemics in aquaculture (Gustafson et al. 2007, Kristoffersen et al. 2009, Salama \& Murray 2011), was much higher in laboratory conditions: animals cohabited in a smaller and more confined environment in the laboratory than in the field, where the infected oysters were several metres away from the healthy ones. Alternatively, the biomass of infectious animals, another important factor in explaining disease epidemics in aquaculture fish species (Salama \& Murray 2011), may be higher in laboratory conditions, where $50 \%$ of the oysters were presumably infected with OsHV-1, than in the field. In support of these 2 hypotheses, survival of exposed and challenged oysters cohabiting in laboratory conditions has also been seen to increase with seawater renewal and decrease as the biomass of infected oysters is increased (B. Petton et al. unpubl.).

\section{Relationship between temperature, OsHV-1 and vibrios}

Levels of OsHV-1 DNA detected in exposed oysters decreased gradually as a function of time, as reported in other recent studies (Dégremont 2011, Pernet et al. 2012). It is therefore likely that oysters infected with OsHV-1 eliminated viral DNA from their tissue. Alternatively, the surviving animals that remained in the tank at the end of the experiment may have had limited OsHV-1 replication.

The rate of OsHV-1 DNA decrease in oysters was accelerated by higher seawater temperatures in previously exposed oysters: at the end of the experimental period, the level of OsHV-1 DNA was $>10^{4}$ copies $\mathrm{mg}^{-1}$ at temperatures ranging between 13.4 and $17.5^{\circ} \mathrm{C}$, whereas it was undetected at temperatures ranging between 21.9 and $29.0^{\circ} \mathrm{C}$. High temperatures may promote antiviral activities in oysters. For instance, a positive correlation between seawater temperature and antiviral activity was reported in the abalone Haliotis rubra (Dang et al. 2012). In Crassostrea gigas, antiviral activity is at its lowest during the spring, in late April and early May, and increases markedly until August, when the highest values are reached (Olicard et al. 2005). These antiviral assays were performed on specimens collected in Marennes-Oléron, a temperate Atlantic coastal area where seawater temperatures generally vary from $\sim 8^{\circ} \mathrm{C}$ during the winter to $\sim 25^{\circ} \mathrm{C}$ during the summer.

Alternatively, the greater elimination of viral DNA at higher temperatures likely reflects changes in 
physiological rates of the host animal. For instance, physiological processes, e.g. assimilation, maintenance and structural growth, in poikilothermic marine animals depend on seawater temperature. Within a species-specific temperature tolerance range, physiological rates increase exponentially with temperature, as described by the Arrhenius relation. For Crassostrea gigas, the lower temperature tolerance boundaries for ingestion and respiration rates are both estimated to be $3^{\circ} \mathrm{C}$, and the upper boundaries to be 25 and $32^{\circ} \mathrm{C}$ for ingestion and respiration rates, respectively (see Bourlès et al. 2009 for review). The application of this temperature tolerance range in the oyster dynamic energy budget model results in a slowing down of oyster growth when temperatures are $>25^{\circ} \mathrm{C}$ (Bourlès et al. 2009). Therefore, the greater elimination of viral DNA at higher temperatures coincides with higher respiration rate (catabolism) and lower ingestion and growth rates (anabolism), which may both contribute to reducing the replication of OsHV-1.

Levels of OsHV-1 DNA in challenged oysters increased over the experimental period until they attained values similar to those observed in previously exposed oysters, and decreased thereafter. For the first time, this study shows that the time required until peak values of OsHV-1 DNA were attained in challenged oysters decreased at higher seawater temperatures. Schikorski et al. (2011a) showed that peak values of OsHV-1 DNA were attained in oysters after $4 \mathrm{~d}$ of cohabitation at $22^{\circ} \mathrm{C}$, which agrees with the results obtained in the present study at $21.9^{\circ} \mathrm{C}$.

Although there was no correlation between temperature and the peak values of OsHV-1 DNA found in oysters grown in cohabitation, it should be noted that the lowest peak value of OsHV-1 DNA was found at $29.0^{\circ} \mathrm{C}$, and coincided with higher survival. Lower peak values of OsHV-1 DNA in oysters held in cohabitation at $29.0^{\circ} \mathrm{C}$ may reflect the lowering of ingestion rates that normally occurs in Crassostrea gigas at temperatures $>25^{\circ} \mathrm{C}$ (see Bourlès et al. 2009 for review). Indeed, a relationship between filtration rate and susceptibility to viral disease could be responsible (Schikorski et al. 2011a). Alternatively, a lower peak value of OsHV-1 DNA in oysters in cohabitation held at $29.0^{\circ} \mathrm{C}$ may also reflect a higher antiviral activity in these animals (see previous discussion).

The number of vibrio CFU detected in oysters previously exposed to field conditions showed no consistent patterns with regard to temperature treatment in our study. Higher vibrio abundances in seawater generally occur at periods with higher temperatures (Vezzulli et al. 2010, Oberbeckmann et al. 2012). For example, concentrations of vibrios in Mediterranean waters are correlated with sea-surface temperature - with few vibrios being counted when temperatures drop below $18^{\circ} \mathrm{C}$ and a sharp increase of abundance when temperatures are $\geq 22^{\circ} \mathrm{C}$ (Vezzulli et al. 2010). In our study, it is likely that the level of vibrio detected in oysters previously exposed to field conditions was mostly driven by the initial field exposure.

However, as observed for OsHV-1 DNA, the time required to attain peak values of vibrio CFU in challenged oysters decreased with increasing seawater temperature. Therefore, high temperatures are likely to facilitate the transmission of vibrios from exposed animals to animals in cohabitation.

\section{CONCLUSIONS}

The present study set out to examine the thermal range for transmission of the disease responsible for the mass mortalities phenomenon in juvenile Pacific oysters. Our results show that the optimal temperature range for disease transmission is between 16.2 and $21.9^{\circ} \mathrm{C}$, which agrees well with field observations. When seawater temperatures were $<13.4^{\circ} \mathrm{C}$, the disease was not transmitted to healthy oysters cohabiting with those transferred from the field. Finally, it seems that oysters previously infected with OsHV-1 could recover after being kept at $13.0^{\circ} \mathrm{C}$ for $40 \mathrm{~d}$. Therefore, our study suggests that long-term holding at low temperatures may offer a way to mitigate oyster mortalities.

Acknowledgements. The authors thank all the staff involved in oyster production at Ifremer Argenton. The authors also express their gratitude to P. Le Souchu for his technical assistance, to $\mathrm{H}$. McCombie for revising the English version of this manuscript and 4 anonymous reviewers for their constructive comments. This work was supported by Ifremer (project 'Surmortalité' 2010-11 coordinated by N. Cochennec-Laureau) and is part of the GIGASSAT project funded by ANR-AGROBIOSPHERE No. ANR-12-AGRO-0001-01.

\section{LITERATURE CITED}

Bedier E (2010) Observatoire national Conchylicole. Rapport 2009. Ifremer, Issy-les-Moulineaux

Berthelin C, Kellner K, Mathieu M (2000) Storage metabolism in the Pacific oyster (Crassostrea gigas) in relation to summer mortalities and reproductive cycle (west coast of France). Comp Biochem Physiol B Biochem Mol Biol 125: 359-369

Bouquet al. Mille D, Blachier P, Oudot G and others (2011) Recherche de solutions zootechniques pour limiter les surmortalités - Bilan des suivis 2010. http://creaa.pagespersoorange.fr/Doc\%20actualite/Rapportzootechnique2010.pdf 
Bourlès Y, Alunno-Bruscia M, Pouvreau S, Tollu G and others (2009) Modelling growth and reproduction of the Pacific oyster Crassostrea gigas: advances in the oysterDEB model through application to a coastal pond. J Sea Res 62:62-71

Burge CA, Griffin FJ, Friedman CS (2006) Mortality and herpesvirus infections of the Pacific oyster Crassostrea gigas in Tomales Bay, California, USA. Dis Aquat Org 72: 31-43

> Burge CA, Judah LR, Conquest LL, Griffin FJ and others (2007) Summer seed mortality of the Pacific oyster, Crassostrea gigas Thunberg grown in Tomales Bay, California, USA: the influence of oyster stock, planting time, pathogens, and environmental stressors. J Shellfish Res 26:163-172

> Dang VT, Speck P, Benkendorff K (2012) Influence of elevated temperatures on the immune response of abalone, Haliotis rubra. Fish Shellfish Immunol 32:732-740

> De Decker S, Saulnier D (2011) Vibriosis induced by experimental cohabitation in Crassostrea gigas: evidence of early infection and down-expression of immune-related genes. Fish Shellfish Immunol 30:691-699

> De Decker S, Normand J, Saulnier D, Pernet F, Castagnet S, Boudry P (2011) Responses of diploid and triploid Pacific oysters Crassostrea gigas to Vibrio infection in relation to their reproductive status. J Invertebr Pathol 106:179-191

> Dégremont L (2011) Evidence of herpesvirus (OsHV-1) resistance in juvenile Crassostrea gigas selected for high resistance to the summer mortality phenomenon. Aquaculture 317:94-98

> Delaporte M, Soudant P, Lambert C, Moal J, Pouvreau S, Samain JF (2006) Impact of food availability on energy storage and defense related hemocyte parameters of the Pacific oyster Crassostrea gigas during an experimental reproductive cycle. Aquaculture 254:571-582

- Di Pinto A, Terio V, Novello L, Tantillo G (2011) Comparison between thiosulphate-citrate-bile salt sucrose (TCBS) agar and CHROMagar Vibrio for isolating Vibrio parahaemolyticus. Food Contr 22:124-127

EFSA (European Food Safety Association) (2011) Scientific opinion of the panel on animal health and welfare on a request from the European Commission on the increased mortality events in Pacific oysters Crassostrea gigas. EFSA 8:1894-1953

Friedman CS, Estes RM, Stokes NA, Burge CA and others (2005) Herpes virus in juvenile Pacific oysters Crassostrea gigas from Tomales Bay, California, coincides with summer mortality episodes. Dis Aquat Org 63:33-41

Garcia C, Thebault A, Degremont L, Arzul I and others (2011) Ostreid herpesvirus 1 detection and relationship with Crassostrea gigas spat mortality in France between 1998 and 2006. Vet Res 42

> Gustafson LL, Ellis SK, Beattie MJ, Chang BD and others (2007) Hydrographics and the timing of infectious salmon anemia outbreaks among Atlantic salmon (Salmo salar L.) farms in the Quoddy region of Maine, USA, and New Brunswick, Canada. Prev Vet Med 78:35-56

Kristoffersen AB, Viljugrein H, Kongtorp RT, Brun E, Jansen PA (2009) Risk factors for pancreas disease (PD) outbreaks in farmed Atlantic salmon and rainbow trout in Norway during 2003-2007. Prev Vet Med 90:127-136

Le Deuff RM, Renault T, Gerard A (1996) Effects of temperature on herpes-like virus detection among hatcheryreared larval Pacific oyster Crassostrea gigas. Dis Aquat Org 24:149-157
Lyman MG, Enquist LW (2009) Herpesvirus interactions with the host cytoskeleton. J Virol 83:2058-2066

- Martenot C, Oden E, Travaille E, Malas JP, Houssin M (2011) Detection of different variants of ostreid herpesvirus 1 in the Pacific oyster, Crassostrea gigas between 2008 and 2010. Virus Res 160:25-31

Oberbeckmann S, Fuchs BM, Meiners M, Wichels A, Wiltshire KH, Gerdts G (2012) Seasonal dynamics and modeling of a Vibrio community in coastal waters of the North Sea. Microb Ecol 63:543-551

Oden E, Martenot C, Berthaux M, Travaillé E, Malas JP, Houssin M (2011) Quantification of ostreid herpesvirus 1 (OsHV-1) in Crassostrea gigas by real-time PCR: determination of a viral load threshold to prevent summer mortalities. Aquaculture 317:27-31

Olicard C, Didier Y, Marty C, Bourgougnon N, Renault T (2005) In vitro research of anti-HSV-1 activity in different extracts from Pacific oysters Crassostrea gigas. Dis Aquat Org 67:141-147

Paillard C, Le Roux F, Borreg JJ (2004) Bacterial disease in marine bivalves, a review of recent studies: trends and evolution. Aquat Living Resour 17:477-498

> Peeler EJ, Reesea RA, Cheslettb DL, Geogheganb F, Powerb A, Thrusha MA (2012) Investigation of mortality in Pacific oysters associated with ostreid herpesvirus- $1 \mu$ Var in the Republic of Ireland in 2009. Prev Vet Med 105: 136-143

> Pepin JF, Riou A, Renault T (2008) Rapid and sensitive detection of ostreid herpesvirus 1 in oyster samples by realtime PCR. J Virol Methods 149:269-276

Pernet F, Barret J, Marty C, Moal J, Le Gall P, Boudry P (2010) Environmental anomalies, energetic reserves and fatty acid modifications in oysters coincide with an exceptional mortality event. Mar Ecol Prog Ser 401:129-146

Pernet F, Barret J, Le Gall P, Corporeau C and others (2012) Mass mortalities of Pacific oysters Crassostrea gigas reflect infectious diseases and vary with farming practices in the Mediterranean Thau lagoon, France. Aquacult Environ Interact 2:215-237

Renault T (2011) A review of mortality outbreaks in the Pacific oyster, Crassostrea gigas, reported since 2008 in various European Union Member States and the related implementation of Council Directive 2008/88/EC. Bulletin OIE 4:51-52

Renault T, Le Deuff RM, Cochennec N, Chollet B, Maffart P (1995) Herpes-like viruses associated with high mortality levels in larvae and spat of Pacific oysters, Crassostrea gigas: a comparative study, the thermal effects on virus detection in hatchery-reared larvae, reproduction of the disease in axenic larvae. Vet Res 26:539-543

Renault T, Moreau P, Faury N, Pepin JF, Segarra A, Webb S (2012) Analysis of clinical ostreid herpesvirus 1 (Malacoherpesviridae) specimens by sequencing amplified fragments from three virus genome areas. J Virol 86: 5942-5947

> Rico-Villa B, Woerther P, Mingant C, Lepiver D, Pouvreau S, Hamon M, Robert R (2008) A flow-through rearing system for ecophysiological studies of Pacific oyster Crassostrea gigas larvae. Aquaculture 282:54-60

> Rico-Villa B, Pouvreau S, Robert R (2009) Influence of food density and temperature on ingestion, growth and settlement of Pacific oyster larvae, Crassostrea gigas. Aquaculture 287:395-401

Salama NKG, Murray AG (2011) Farm size as a factor in hydrodynamic transmission of pathogens in aquaculture 
fish production. Aquacult Environ Interact 2:61-74

Samain JF, McCombie H (2008) Summer mortality of Pacific oyster Crassostrea gigas, the Morest project. QUAE/ Ifremer, Versailles

Saulnier D, De Decker S, Haffner P, Cobret L, Robert M, Garcia C (2010) A large-scale epidemiological study to identify bacteria pathogenic to Pacific oyster Crassostrea gigas and correlation between virulence and metalloprotease-like activity. Microb Ecol 59:787-798

Sauvage C, Pépin JF, Lapègue S, Boudry P, Renault T (2009) Ostreid herpes virus 1 infection in families of the Pacific oyster, Crassostrea gigas, during a summer mortality outbreak: differences in viral DNA detection and quantification using real-time PCR. Virus Res 142:181-187

Schikorski D, Faury N, Pepin JF, Saulnier D, Tourbiez D, Renault T (2011a) Experimental ostreid herpesvirus 1 infection of the Pacific oyster Crassostrea gigas: kinetics of virus DNA detection by q-PCR in seawater and in oyster samples. Virus Res 155:28-34

Schikorski D, Renault T, Saulnier D, Faury N, Moreau P, Pepin JF (2011b) Experimental infection of Pacific oyster Crassostrea gigas spat by ostreid herpesvirus 1: demonstration of oyster spat susceptibility. Vet Res 42

Editorial responsibility: Megan La Peyre, Baton Rouge, Louisiana, USA
Segarra A, Pepin JF, Arzul I, Morga B, Faury N, Renault T (2010) Detection and description of a particular Ostreid herpesvirus 1 genotype associated with massive mortality outbreaks of Pacific oysters, Crassostrea gigas, in France in 2008. Virus Res 153:92-99

Soletchnik P, Razet D, Geairon P, Faury N, Goulletquer P (1997) Ecophysiology of maturation and spawning in oyster (Crassostrea gigas): metabolic (respiration) and feeding (clearance and absorption rates) responses at different maturation stages. Aquatic Living Res 10:177-185

Soletchnik P, Faury N, Goulletquer P (2006) Seasonal changes in carbohydrate metabolism and its relationship with summer mortality of Pacific oyster Crassostrea gigas (Thunberg) in Marennes-Oléron bay (France). Aquaculture 252:328-338

Vezzulli L, Previati M, Pruzzo C, Marchese A, Bourne DG, Cerrano C, the VibrioSea C consortium (2010) Vibrio infections triggering mass mortality events in a warming Mediterranean Sea. Environ Microbiol 12:2007-2019

> Webb SC, Fidler A, Renault T (2007) Primers for PCR-based detection of ostreid herpes virus-1 (OsHV-1): application in a survey of New Zealand molluscs. Aquaculture 272: 126-139

Submitted: January 7, 2013; Accepted: April 15, 2013 Proofs received from author(s): May 14, 2013 